\title{
Media Use and Its Effects in a Cross-National Perspective
}

\author{
Hajo G. Boomgaarden · Hyunjin Song
}

Published online: 6 May 2019

(C) The Author(s) 2019

\begin{abstract}
This contribution provides a critical reflection on the state-of-the-art of cross-national media use and media effect studies. Increasing availability of data sources, advances in theorizing and facilitation of international research collaboration have contributed to an increasing application of cross-national perspectives in communication research. Contingencies of media use and media effects brought about by national media systems or sociopolitical and cultural contexts of media use have become a central tenet of such research. The paper starts out by discussing the need for cross-national comparative perspectives in communication research. It then goes on to review the generally problematic nature of "media use" measurement, in particular in a comparative perspective, followed by an introduction to media systems and information environments as among the central macrolevel concepts in media use and media effect studies. In its core, the contribution reviews multilevel studies examining media use and the impact had by media, most of which stem from the realm of news use and its effects in politics. The article then discusses whether and to what degree these cross-national studies have contributed to further theory building. It concludes by discussing and providing an outlook for the future of comparative communication research.
\end{abstract}

Keywords Media use - Media effects - Comparative communication research . Measurement

\footnotetext{
H. G. Boomgaarden $(\bowtie) \cdot$ H. Song

Department of Communication, University of Vienna

Rathausstraße 19/1/9, 1010 Vienna, Austria

E-Mail: hajo.boomgaarden@univie.ac.at

H. Song

E-Mail: hyunjin.song@univie.ac.at
} 


\section{Mediennutzung und ihre Auswirkungen in einer länderübergreifenden Perspektive}

Zusammenfassung Dieser Beitrag liefert eine kritische Reflexion über den Stand der länderübergreifenden Studien zu Mediennutzung und Medienwirkung. Die zunehmende Verfügbarkeit von Datenquellen, Fortschritte in der Theoretisierung und Erleichterung der internationalen Forschungszusammenarbeit haben zu einer zunehmenden Anwendung länderübergreifender Perspektiven in der Kommunikationsforschung beigetragen. Kontingenzen der Mediennutzung und Medieneffekte, die durch nationale Mediensysteme oder gesellschaftspolitische und kulturelle Kontexte der Mediennutzung hervorgerufen werden, sind zu einem zentralen Grundsatz dieser Forschung geworden. Das Papier beginnt mit der Diskussion über die Notwendigkeit länderübergreifender vergleichender Perspektiven in der Kommunikationsforschung. Anschließend wird die allgemeine Problematik der Messung von „Mediennutzung“, insbesondere in vergleichender Perspektive, untersucht, dem folgt eine Einführung in Mediensysteme und Informationsumgebungen als zentrale Konzepte der Mediennutzungs- und Medienwirkungsstudien auf Makroebene. Im Kern werden in dem Beitrag Mehrebenenstudien betrachtet, die die Mediennutzung und die mediale Wirkung untersuchen, von denen die meisten aus dem Bereich der Nachrichtennutzung und ihrer Auswirkungen in der Politik stammen. Darüber hinaus wird in dem Artikel erörtert, ob und inwieweit diese länderübergreifenden Studien zur weiteren Theoriebildung beigetragen haben. Abschließend wird ein Ausblick auf die Zukunft der vergleichenden Kommunikationsforschung gewährt sowie darüber diskutiert.

Schlüsselwörter Mediennutzung · Medienwirkung · Vergleichende Kommunikationsforschung $\cdot$ Messung

\section{Introduction}

The media have taken central stage as drivers and facilitators of a great range of social, psychological or political processes (Bryant and Oliver 2009). They for instance appear as a main source of information for sociopolitical engagement (Anduiza et al. 2012; Beck et al. 2002; McLeod et al. 1999), and thereby contribute to the (mal)functioning of democracy (Curran 2011; Delli Carpini and Keeter 1993). While being a main source of one's social identities (Slater 2007, 2015), they are considered a threat to social cohesion (Putman 2000), as well as a factor producing social capital (Shah et al. 2001; Campbell and Kwak 2010). They are seen as a major source of pleasure, relaxation, and gratification (Zillmann 1988; Vorderer et al. 2004), but are also associated with decreased well-being (such as loneliness and depression) and problematic behaviors (Becker et al. 2013; Kim et al. 2009). Hence a systematic engagement with questions about why it is that people are using media, and what the consequences of media use are for cognitions, attitudes and behaviors, has been characterizing empirical studies in communication science.

Broadly classified as transmitters of information between senders and receivers, media are broken down into those types with a purely technological function (such 
as the Internet or a telephone) and those which are involved not only with the transmission, but more importantly with the selection and packaging of information (e.g., traditional mass media outlets, social media). Interactivity has become more prominent in recent decades, with the boundaries between senders and receivers of information becoming increasingly blurred (Neuman 2016). While the sheer usage of different types of media is the focus of a rich research tradition (Althaus and Tewksbery 2000; Katz et al. 1973; Sears and Freedman 1967) including various motivations, needs, and predispositions that underlie such media usage patterns (e.g. Donohew et al. 1987; Wang et al. 2012), at least an equally prominent tradition is formed by research looking at the consequences of such media usage for a variety of cognitive, emotional, attitudinal or behavioral outcomes and their contingency conditions (e.g. Bryant and Oliver 2009; Nabi and Oliver 2009; Potter 2011; Valkenburg and Peter 2013). These two research traditions, taking individual media use as either an outcome or as an explanatory variable, are at the heart of this contribution.

Media use has been largely treated as an individual-level construct, with individuals more or less consciously and voluntarily deciding to turn their attention toward any types of mediated communication. Factors influencing individuals' media diets relate to information seeking, motivations and needs, or personal predispositions (Bartsch et al. 2006; Blumler 1979; Ruggiero 2000). Media use, then, has been shown to affect a range of "individual" outcomes along the continuum of cognition, affect, attitudes, and behaviors (e.g. Bryant and Oliver 2009). Such individual media use does not however take place in a vacuum, but is hosted in a range of contextual levels, including families, neighborhoods, or media markets (Slater et al. 2006). While one's microsocial settings-namely interpersonal influences-during communication, or in the pre- and postcommunicative phase have been acknowledged and subject to empirical investigation (e.g. Boomgaarden 2014; Schmitt-Beck 2003; Southwell and Yzer 2007), larger contexts and environments and how they interact with individual media use have been somewhat neglected for quite some time (Pan and McLeod 1991): "communication continues to be dominated by research at the individual level of analysis" (McLeod et al. 2010, p. 183).

It could be argued that such an individual, microlevel focus on communication (a) neglects a larger contextualization of research findings, (b) thereby ignores debates of universal applicability and generalizability versus the context dependency of empirical findings, and as a consequence, (c) misses out on the opportunities for further theorizing and theory refinement regarding media use and its effects. Considering media use as embedded in higher-level structures will thus enable a more comprehensive, encompassing, and arguably the theoretically enhanced understanding of the role of media in contemporary societies. "The lack of theoretical and empirical connections between levels has produced explanations of communication phenomena that center on internal mental states rather than on social, economic and political conditions" (McLeod et al. 2010, p. 184). Such a line of argument has certainly gained in relevance, given the rapidly changing contexts in which communication takes place, in terms of advancements of communication technologies and ever-growing distribution of such technologies, and in terms of economic and cultural global interconnectedness as a consequence of communication technologies (McLuhan and Powers 1989; Castells 2011). As recently argued, "scholars have be- 
come sensitive to the contexts of democratic development, sociocultural influences and economic (de)regulation and eventually drastic changes in information environments to shape citizens' media and political roles" (Pfetsch and Esser 2014). This contribution addresses the degree to which a systematic contextualization of media practices indeed takes place in the current empirical literature.

In a seminal paper, McLeod and Blumler (1987) provide three major reasons for serious consideration of the macrolevel in media and communication studies: (a) generating a more comprehensive understanding of media processes, (b) making the field relevant for public policy making, and (c) recognizing that economic, social and technological contexts are theoretically important factors in media use and their effects. With increasing trends of globalization and transnationalization of media, "it is no longer plausible to study a phenomenon in one country without asking whether it is common across the globe or distinctive to that specific context" (Esser and Hanitzsch 2012, p. 3). And if the latter is true, it is indeed imperative to understand why that may be the case, addressing the specificity and generalizability of one's findings across different geographical, national, or cultural contexts (Livingstone 2003). Consequentially, communication has been devised as a cross-level "variable" field, rather than a single "level" field (Paisley 1984). ${ }^{1}$

Following Edelstein's (1982, p. 14) definition, we conceptualize comparative communication (or comparative media) research as "a study that compares two or more nations with respect to some common activity" with the theoretical focus of such comparison of "common activity" being media use and effects. At the very basic level, comparative research on media processes, if it takes seriously the interdependencies of individual and contextual variables, "creates a need to think structurally, to conceptualize in macro terms, to stretch vertically across levels and horizontally across systems" (Blumler et al. 1992, p. 8). Context can be close to communication phenomena (such as media systems or information environments, see further below), or more remote but still bearing theoretical relevance (e.g. differences in culture, values, or political systems). Following McLeod et al. (2010, p. 192), contexts "are broadly defined as properties of macro-units that operate as constraints, shaping individual-level (or lower-level) phenomena through incentives or reducing patterns by deterrents or sanctions." Comparative communication research therefore "attempts to reach conclusions beyond single systems or cultures, and explains differences and similarities between objects of analysis against the backdrop of their cultural conditions" (Esser and Hanitzsch 2012, p. 5). Ultimately it is about understanding how characteristics of the contextual environment in which individual media users are situated shape their communication processes, and how such processes vary across different settings (Blumler and Gurevitch 1995).

Truly comparative communication research has been a marginal field for a long time, and even today the spread of comparative approaches is rather uneven across different subfields of the discipline. Most common, if comparative perspectives are taken into account, are studies that would be classified as "comparative case studies"

\footnotetext{
1 According to Paisley (1984), "variable" fields tend to focus on a single "variable" (e.g. communication) across all levels of analysis, whereas "level" fields tend to fix their levels of analysis and focus on all relevant variables within such a single level.
} 
in which at most two (more or less) identical studies in two different contexts are compared (or single cases are contrasted to prior empirical observations in the framework of prototypical or deviant cases). These are what Vliegenthart (2012) would coin as descriptive, or basic explanatory, comparative designs that rely at most on a qualitative comparison between different cases, in light of the logic of most similar or most different system designs (Teune and Przeworski 1970). Studies that formally compare more than two contexts from an (explicit) crossnational perspective are somewhat less common. Such studies appear to constitute the standard for comparative research in many areas of media use and media effect studies (Esser and Hanitzsch 2012, p. 13), often taking the form of "comparison of relations" (Vliegenthart 2012, p. 487), albeit such applications are still rare compared to a merely descriptive comparative design.

Large-N, multilevel comparative approaches and applications of cross-national perspectives to individual-level media processes have been increasing in the past two decades. Sparked to some degree by studies in the subfields of journalism (Hanitzsch et al. 2011) and political communication (Esser and Pfetsch 2004), and given great impetus by a special issue of Human Communication Research (Slater et al. 2006), such comparative perspectives have entered the stage in several subfields (see the collection by Esser and Hanitzsch 2012, for an extensive review). Such studies have drawn on large-scale cross-national research projects such as World of Journalism, Providing an Infrastructure for Research on Electoral Democracy in the European Union (PIREDEU), Cooperation in Science \& Technology (COST), Action Populist Political Communication in Europe, World Values Survey (WVS), European Election Studies (EES), or the European Social Survey (ESS). Collaborative efforts on the part of international networks of scholars such as the Network of European Political Communication Scholars (NePoCS) or the Comparative National Election Project (CNEP) also have played a critical role in increasing the availability of appropriate data sources for research on media use and their effects. These have in turn brought about advances when it comes to theorizing the contingencies of media use and their effects triggered by national media systems or sociopolitical and cultural contexts.

This contribution focuses on reviewing the state-of-the-art of the latter category of comparative media use and media effects studies, considering only those empirical contributions that, at the very least, employ multilevel models explaining either media use or looking at the effects of individual media use while taking into account country-contextual variation. Within such an explicit focus on multilevel modeling studies, it appears that these largely stem from the broad subfield of political communication, which is arguably due to the nature of the data sources in use. Before reviewing the individual contributions from the field, it appears imperative to briefly discuss two central variables and their measurement problems in a comparative perspective, on individual-level media use (or media exposure) and on the contextual level of media systems and information environments. As will subsequently become evident, while the large-N, multilevel comparative approaches using multilevel linear modeling (MLM) literature on media effects have gained some momentum over the past decade, literature on explanations of media use across countries and taking contextual variation into account is still in its infancy. We will conclude with a discussion of potential future avenues and challenges to such comparative endeavors. 


\section{Conceptual and Empirical Considerations}

\subsection{Comparative Measurement of Media Use}

The measurement of media use is central to answering individual-level questions regarding explanations of time investment into media reception or the consequences of the media. We speak of media use and media exposure as synonyms here, the former being more of a tradition in reception research (with the idea of using media for a given purpose), the latter more of a tradition in effects research. Media use is a quantitative measure of self-reported time spent on using media in general, or certain subcategories of media or media outlets, or of the frequency of use of such media in a given timeframe (e.g. per week or month). While it is nowadays often included in different kinds of survey research (e.g. election studies, social surveys), the measurement of media use is by no means unproblematic (Slater 2004). A vibrant debate revolves around the potential of overreporting media use (e.g. Prior 2009a, 2009b), alternative measurements (Dilliplane et al. 2013; Prior 2013) and possible ways ahead to come to theoretically useful and methodologically valid measures (de Vreese and Neijens 2016).

It could be argued that the measurement problem is considerably enlarged in the case of comparative cross-country surveys. It is important here to distinguish between media use in more general terms, and genre- or outlet-specific media use. The former for instance asks how many hours per week an individual spends watching $\mathrm{TV}$, how many days per week (s)he reads a printed newspaper, or how many minutes (s)he spends per day using social media. These categories are more or less readily comparable between countries or media systems. From an analytical point of view, however, such "overall time spent" measures appear somewhat less useful given the very generic and content-agonistic nature of the measurement instruments. In contrast, the latter (outlet-specific) media use measures would for instance probe the readership of a particular newspaper title, watching a particular television show, or following a certain actor on social media. For media effects research in particular, in which knowledge about the particular contents to which people are exposed matters, such measurement is often to be preferred, allowing for linkage approaches integrating media content and exposure measures (de Vreese et al. 2017). Such categories are however much more difficult to validly measure and standardize across different national contexts in a comparative perspective, given the particularities of national media systems. The literature hence faces a friction between the robustly comparable measurement of broader categories, and more detailed, analytically more useful, but certainly less comparable and more demanding, measures of detailed, outletspecific exposure.

International survey programs reflect this diversity of approaches. The European Social Survey, for instance, has always used rather generic questions on media use, probing the total time spent watching television, and the time spent watching news and current affairs on television (until wave 7), or the total time spent watching, reading or listening to news about politics and current affairs, and the time spent using the Internet (wave 8 onwards). A similar focus on political information is seen in the European Values Study (2008), which asks whether respondents actively 
follow politics in the news on television, on the radio and in the newspapers, all in one question. The World Values Survey (2010-2014) also takes a fairly generic approach, and asks about the frequency of using different types of media, such as newspapers, magazines, television news or the Internet. The European Election Study $(2009,2014)$ includes an intense battery of media use questions, probing the frequency of use of particular media outlets in the different countries, both television and newspapers. While such outlet-specific measurement, which naturally is limited to a number of outlets per country, may not capture all the details of every individual's media use, it is analytically valuable in connection with measures of media content. Interestingly, the literature has not so far paid sufficient attention to estimations or evaluations of the measurement equivalence of media use measures across countries (Hanitzsch and Esser 2012).

\subsection{Nations as Units: Media Systems and Information Environments}

Much comparative research, in particular in the realm of political communication, relies on the macrolevel classification of nations and countries along the lines of different media systems or information environments, sometimes broadly termed as "opportunity structures" for media exposure. ${ }^{2}$ As is further discussed below, the organizational structure of media is supposed to influence individual media use or structure relationships between media use and other outcome variables. While it is increasingly contended that the nation itself may not be the most appropriate unit of analysis (Livingstone 2003), the idea of classifying countries originated from the work aiming to understand differences in how the press are organized (Siebert et al. 1956), identifying four ideal types (libertarian, social responsibility, authoritarian and Soviet-type models). Extending this line of work, and taking up extensions proposed by Blumler and Gurevitch (1975), the seminal work of Hallin and Mancini (2004) paved the way for a strong acknowledgement of media systems in comparative communication research. The authors develop a typology of media systems based on four empirical dimensions: (1) degree of state interventionism, (2) degree of press-party parallelism (Seymour-Ure 1974), (3) professionalization of journalism, and (4) degree of commercialization, resulting in three ideal types: (1) liberal model, (2) democratic corporatist model, and (3) polarized pluralist model. Such media systems then "describe typical patterns of how journalism cultures, media policy, media markets and media use are connected in a given society" (Brüggemann et al. 2014, p. 1038). The model has been recently extended to non-Western contexts (Hallin and Mancini 2012), and subject to rigorous empirical investigations, resulting in a somewhat revised typology (Brüggemann et al. 2014). Implementation of such macrolevel, media system structures into comparative research strongly depends on the available data, which are either combined from a variety of sources and sometimes imperfect in their operationalization (Brüggemann et al. 2014), or gathered through indirect sources such as expert interviews (Popescu et al. 2011).

\footnotetext{
2 Sometimes these are not necessarily identical to country units, such as two different media systems in Belgium (due to language differences) or smaller media markets (designated market area, or DMA) in the U.S., where such different opportunity structures exist within a single country.
} 
Beyond the structural characteristics of media systems, recent research increasingly acknowledges the importance attached to information environments as macrolevel characteristics ${ }^{3}$ influencing microlevel media consumption processes. Such information environments consider the total information available to people within the boundaries of media systems (Pfetsch and Esser 2014). Information environments are therefore empirical observations of outputs of media sources routinely available to national audiences (Esser et al. 2012). As such, they may determine individual media use and their effects by offering opportunity structures of encountering certain types of information. It is argued that information environments are tied to media systems in the sense that certain structural characteristics would favor or be biased towards certain types of information flows (Aalberg et al. 2010). Comparative research then focuses on identifying and isolating a certain characteristic of this information environment, aggregated to the country level. Measurement of such characteristics is, however, demanding since it requires actual media output data from a great range of country contexts. While this used to be only realizable via large-scale projects in which media analysts working in a variety of languages are employed (e.g. PIREDEU), nowadays there is an increasing potential for (semi-) automated procedures to analyze media outputs from a variety of languages and sources (e.g. Proksch et al. 2018; Lind et al. n.d.).

\section{Comparative Research on Media Use}

A long research tradition on predictors and correlates of media use has generally pointed to individual-level factors such as socioeconomic status and education (Livingstone 1998), interest and motivations (Blumler 1979; Knobloch 2003; KnoblochWesterwick and Kleinman 2012; Papacharissi and Rubin 2000; Price and Zaller 1993), or demographic characteristics such as age, gender or race (Lauf 2001; Livignstone 1998; Roe 2000). These approaches very much reflect theorizing that focused on intrinsic motivations and gratifications that individuals sought from media consumption in order to explain why certain individuals consume certain media or genres. Literature addressing this topic from a comparative perspective however generally holds that, as previously acknowledged, "communication not only reflects one's individual predispositions but also the nature of one's social environment" (Cho 2011, p. 434). Motivated by such a principle, indeed many cross-national comparative media studies explicitly aim to understand the degree to which, how and why people prefer to see certain media or genres over others as a function of some national, cultural, or media system-level differences across nations (Althaus et al. 2009; McLeod and Lee 2012). Below, we review and highlight a fairly comprehensive, but not exhaustive, set of exemplary studies on the topic of explanations and correlates of media use. Table 1 gives a broad overview in alphabetical order of the studies reviewed in the following sections, with their key constructs regarding cross-national differences in media use and their effects.

\footnotetext{
${ }^{3}$ This is not to be confused with "individual-level" information environments, which denote the total diet of information consumed by individuals (Jerit et al. 2006).
} 


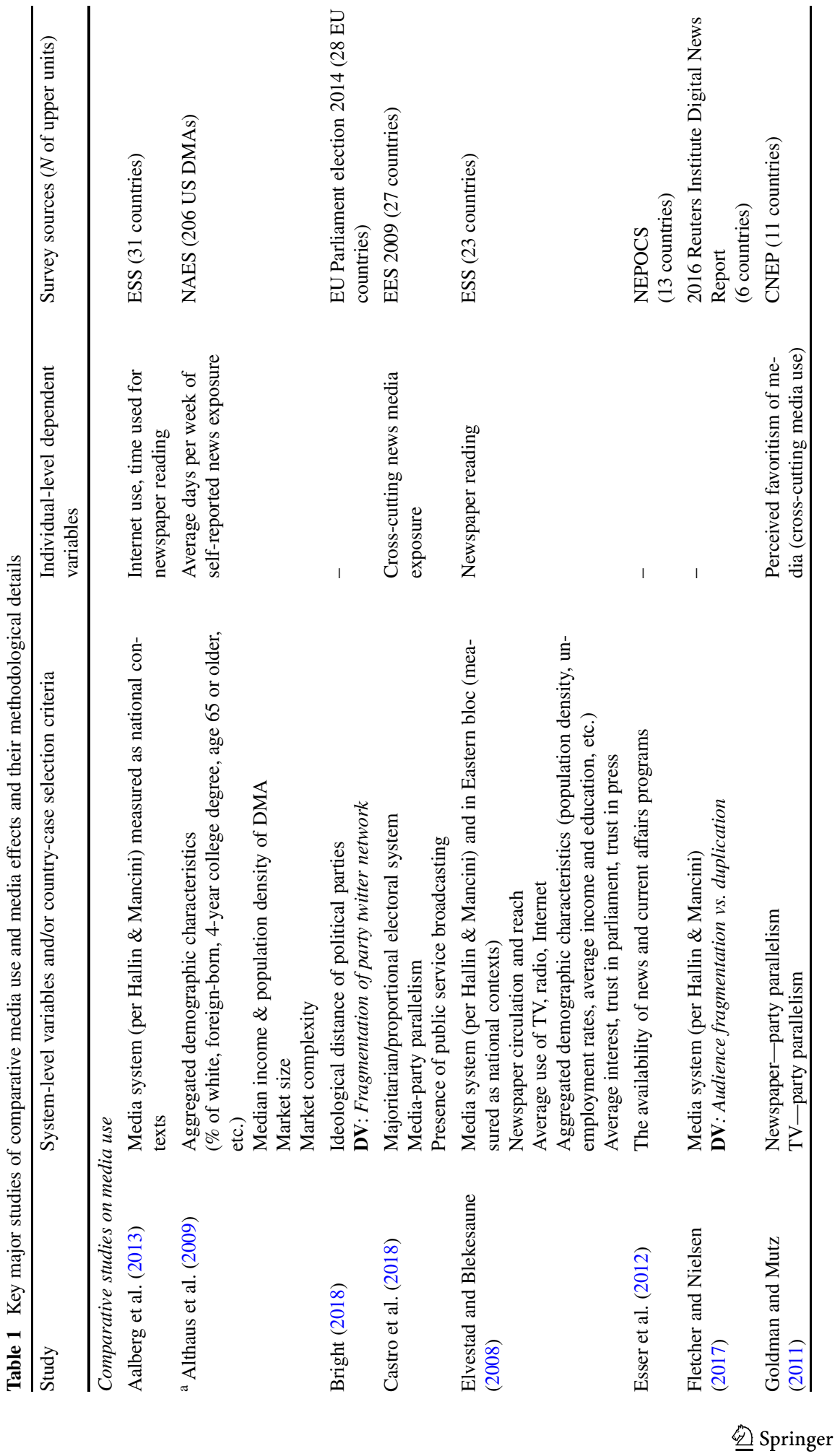




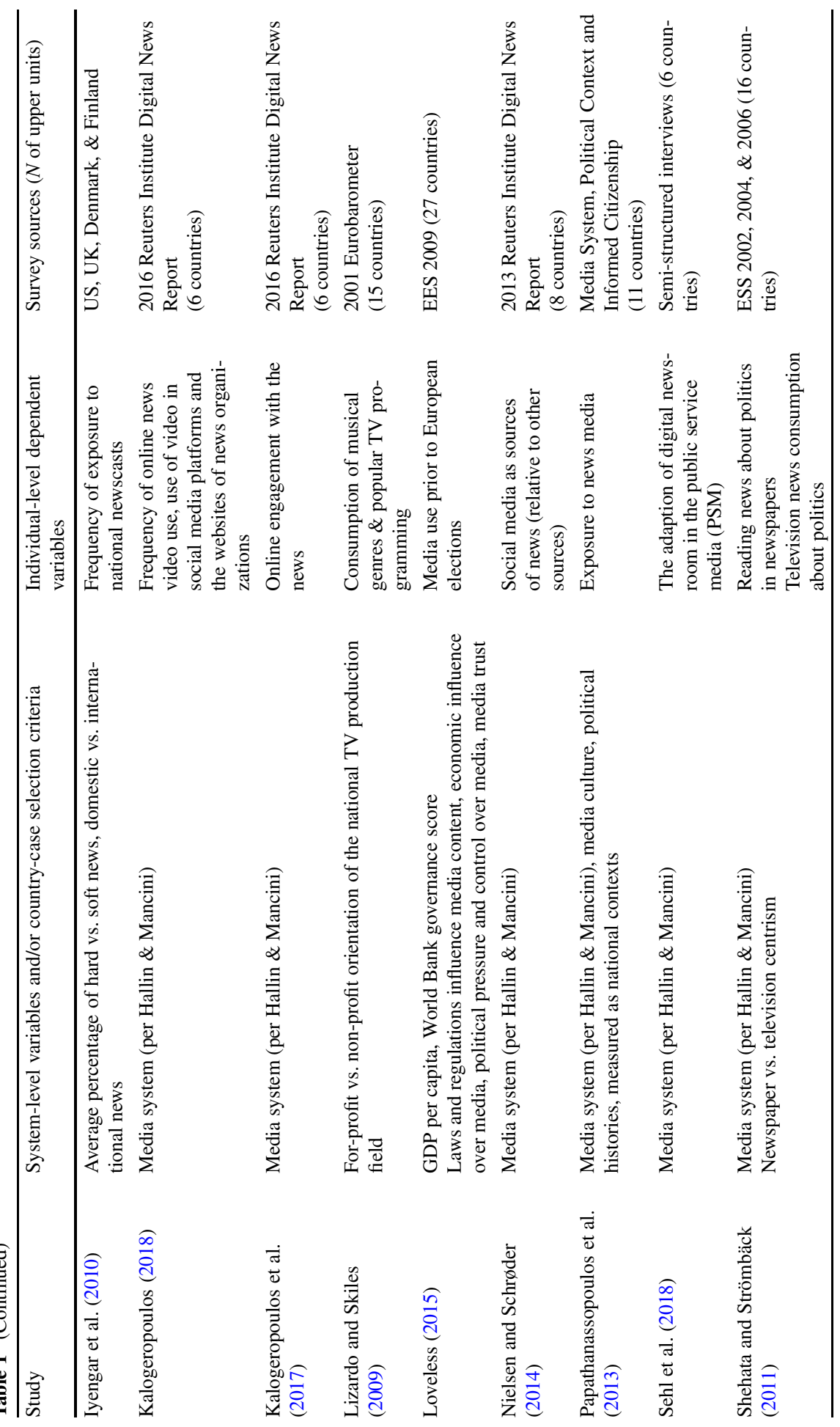




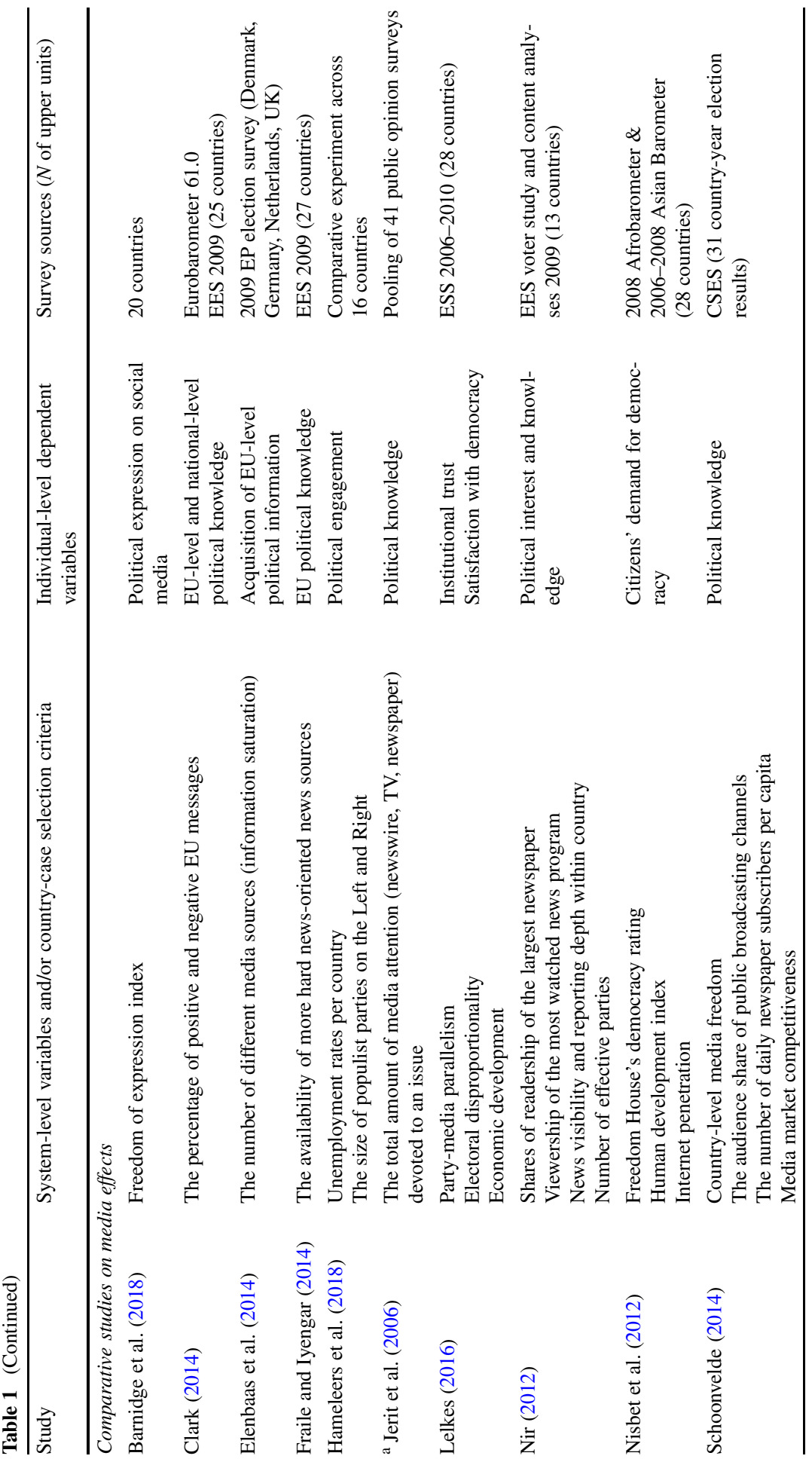




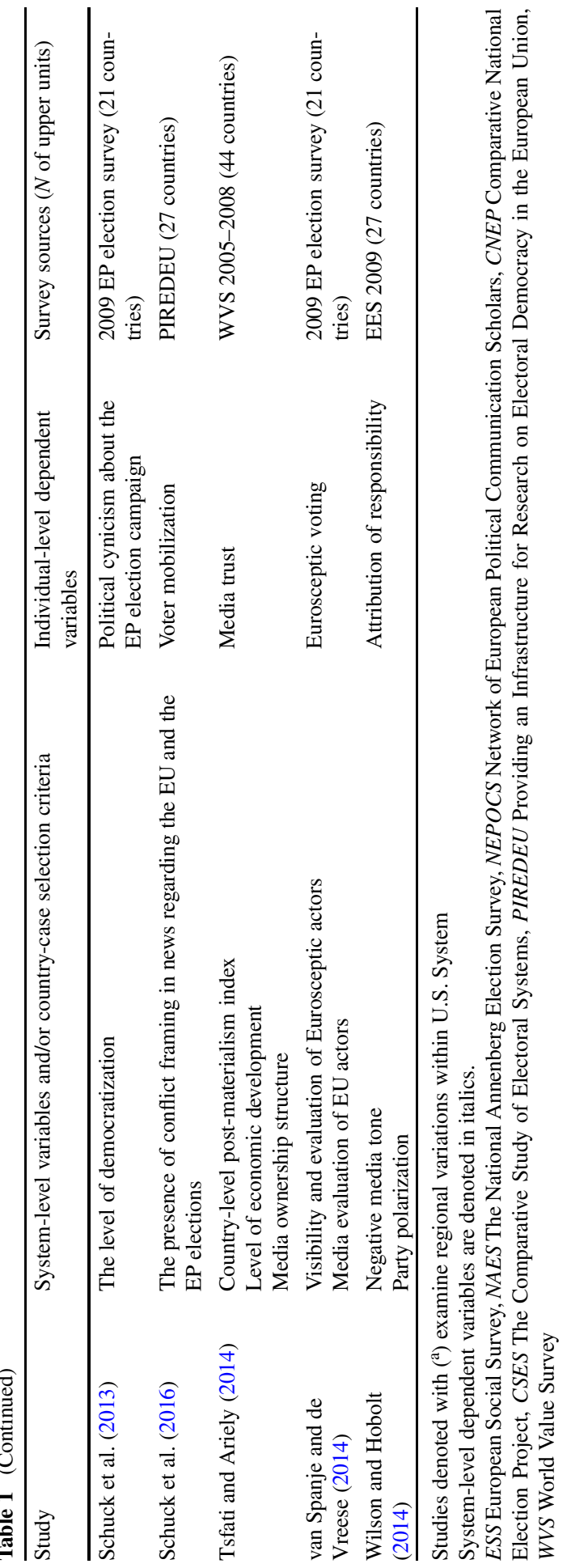


Aalberg et al. (2013; also see Blekesaune et al. 2010) looked at European Social Survey data from 31 European countries, and found that different political regime classifications of countries-specifically Anglo-Saxon and Eastern regimes where a greater choice of television channels and programming is available-have significantly stronger media consumption gaps in terms of time spent watching television in general, versus consumption of news on politics and current affairs. The difference between the time spent watching television in general, and the time spent on news and current affairs, is therefore more/less pronounced in countries with a wider variety of television channels and programming. Papathanassopoulos et al. (2013) observation of 11 countries on four continents across the globe somewhat directly echoes this observation, documenting that complexities of information markets, such as high penetrations of broadband Internet, have a direct bearing on exposure to news at the individual level. Consistent with Prior's (2007) observation, they found that increasing media choices might have led to an increasing gap between exposure to entertainment and news consumption, but to different degrees depending on the availability of access to different information sources.

Explicitly formalizing how contextual differences across U.S. media markets might stimulate patterns of individual-level exposure, Althaus et al. (2009) examine relative contributions made by individual- and contextual-level predictors when it comes to explaining individual-level local and national news exposure. They found that market-level demographic compositions (such as the percentage of the white population, median household income, etc.), market size and differentiation, and the spatial structure of media markets (e.g. the spillover of broadcast signal propagation from neighboring media markets) uniquely influence individual-level TV news exposure. Within the context of Europe, and focusing on newspaper reading behavior, Elvestad and Blekesaune (2008) also found significant influences of certain national-level variations such as unemployment rates, population density, and most importantly media system differences (Northern European or democratic corporatist countries, per Hallin and Mancini's (2004) classifications) in explaining higher newspaper consumptions across Europe. Goldman and Mutz's (2011) investigation examined the extent of cross-cutting exposure from media (operationalized as the distance between perceived political bias of the media and respondents' own political viewpoint), and found that cross-cutting exposure through newspaper and television news programs is negatively related to higher levels of press-party parallelism at the national level. Overall, the studies reviewed above point to the importance of taking into account media system-related variations, as these directly affect consumption patterns across and within media genres.

While most of the aforementioned studies have generally shifted the theoretical focus from individual-level predictors to contextual/system-level predictors, Shehata and Strömbäck's (2011) observation regarding news consumption in 16 European countries represents another stream of thought in this tradition. In that vein, their analysis sheds light on methods to conceptualize and statistically model complex interactions between individual- and contextual-level factors in predicting one's media consumption. Utilizing a set of cross-level interactions, they provide insights into how contextual factors (e.g. a country's newspaper- vs. television-centrism) can further condition the influence of one's motivations and interests, with these factors 
playing a stronger role in countries with more newspaper-centric media environments (such as northern European countries) than television-centric countries (as in Southern European countries). Using the 2009 European Election Study across 25 countries, Loveless' (2015) research also does a good job of exemplifying a typical theoretical setup of treating individual-level "media use" as a dependent variable, being explained by certain contextual variations focusing on system-level characteristics (e.g. media-system differences) and their interaction with individual-level correlates. His study finds some indication that individual-level political interest and national-level journalistic autonomy and professionalism significantly interact with each other in predicting media use. Similarly, in a recent study by Castro, Nir, and Skovsgaard (2018), the impact of an individual's political interest on his or her exposure to (politically) cross-cutting media contents is found to be contingent upon the relative strength of public service broadcasting. They found that the presence of strong public service broadcasting minimizes the opportunities for selectively avoiding non-like-minded contents, echoing the view that one's use of media is shaped by both opportunities (from contextual factors) and motivations (from individual factors). Similar approaches and findings are provided by, for example, Iyengar et al. (2010). Hence, in addition to media system characteristics bearing direct relevance as opportunity structures that would explain individual consumption, these studies emphasize the conditioning role of context in structuring the importance of individual-level factors, above all motivation and interest. In sum, this body of literature stresses the need to investigate media use patterns beyond the peculiarities of national media systems in order to come to a comprehensive understanding.

While the aforementioned studies of cross-national comparison of (individuallevel) media use have constituted the majority of the research tradition, it is indeed not uncommon to find studies that go beyond simple exposure to traditional media, examining interactive, digital narrowcast (social) media. With the advent of alternative forms of media content consumption driven by technological advancements, in particular the spread of digital and mobile media, and by organizational changes in newsrooms across the globe that aim to facilitate news production for different media platforms, there has been a substantial increase in academic attention to the issue of social media and audiovisual consumption (Bright 2018; Kalogeropoulos 2018; Nielsen and Schrøder 2014), along with audience engagements in such new media platforms (Kalogeropoulos et al. 2017). Furthermore, spatial and temporal structural changes in media ecosystems - such as digital newsroom integration into public service media (Sehl et al. 2018), or changes in opportunity structures of information environment (Esser et al. 2012) — are increasingly subject to cross-national comparative analysis. Some recent work on this area has also examined the extent of audience fragmentation across different news media platforms (Fletcher and Nielsen 2017), or day-to-day media diets such as television programming (Lizardo and Skiles 2009) through the lens of comparative, cross-national research. For instance, Fletcher and Nielsen (2017) have found that, while online news audiences are not more fragmented than offline news audiences, there seems to be a higher degree of audience fragmentation in countries with media organizations that offer more diverse content with a high proportion of hard news (e.g. the United Kingdom and Denmark, compared to Spain and the United States), largely because of the dom- 
inance of very strong, powerful sources with a very high reach. Similarly, Lizardo and Skiles (2009) have found that, in countries with relatively more commercialized, profit-oriented market systems (such as England, France, or Germany), consumers with a more highbrow taste are less likely to report having watched a broader range of television programming than those who reside in less commercialized markets (such as in Austria, Finland, and Denmark).

\section{Comparative Research on Media Effects}

Along with the study of media use and its correlates, studies of media "effects" are another fundamental aspect of communication research (for a broad review, see Bryant and Oliver 2009). While the bulk of traditional media effect studies tries to identify why and how certain media use (or exposure) would produce observed affective, cognitive, or behavioral outcomes, comparative studies of media effects tend to focus on their boundary conditions across different national-contextual differences. When and in which contextual circumstances media effects occur, or in which contexts the presence of media effects would diminish, are central questions in this area of research. Theoretically, this inclusion of context often takes the form of focusing on different "opportunity structures" represented by the contextual variations of, for instance, media systems, press-government relations, or the supply of certain types of media programming or contents across countries, on the one hand, and how such variations may in turn produce or further condition the effects of given media exposure on the outcome variables in question, on the other. Methodologically, this is often achieved by linking traditional survey data across countries with respective media content data, sometimes on both the aggregate and on individual levels ("linkage studies": de Vreese et al. 2017). Here, we also include any studies conceptualizing "media exposure" or "media use" as moderating factors of other theoretically relevant variables (such as political ideology) in explaining one's political cognitions or attitudes in this classification, given its theoretical focus of media consumption predicting a dependent variable of interest.

A considerable portion of prior work on this topic has examined the impact of one's mass media use on political knowledge or political engagement and, furthermore, how and why contextual variation across different national contexts can influence this link. These works are motivated at least in part by the observation that, while media exposure in general is related to political learning and, as a result, to political engagements (Carpini and Keeter 1996; Eveland 2001), it appears that the extent of such a relationship is highly variable across different geographical contexts, presumably contingent upon what is actually transmitted by different media (Fraile and Iyengar 2014). It therefore logically follows that any contextual variations in terms of journalistic norms, the degree of commercialization, or the sheer number of choices between news vs. entertainment - all of which can systematically affect the content and frequency of news programming - may affect the relationship between news media exposure and political knowledge and/or engagement.

Using 2009 European Election Study data from 13 EU Member States, Nir (2012) documents that the higher the country-level media fragmentation (operationalized 
as the circulation/viewership share of the largest newspaper/TV news) across different EU Member States, the higher the knowledge gaps are between the top and bottom socioeconomic quartiles. This approach is directly echoed in Elenbaas et al. (2014) research, where they found the more "saturated" (i.e. the level of crossmedia diffusion of the same information across different media) media environment additionality moderate the impact of one's motivation on political learning from media exposure. Yet they also have found that this moderating relationship does not appear to be strictly monotonic. Fraile and Iyengar (2014) also found that the availability of more hard news-oriented news sources (i.e. public broadcasting and broadsheet newspapers) increases the impact of weekly media exposure on citizens' level of political knowledge. Focusing on institutional factors across 31 countries around the globe, Schoonvelde (2014) found that the less governments interfere in media environments, the higher the levels of citizens' political knowledge as a function of personal educational attainments. Similarly, using Eurobarometer data, Clark (2014) observed that more media coverage of European politics at the national level increases citizens' knowledge about EU-related issues, thus confirming the expectation that variations of information "availability" or "opportunity" significantly shape personal knowledge above and beyond any individual-level predictors of political knowledge. Applying a similar logic yet focusing on the U.S. context, Jerit et al. (2006; also see Jerit 2009) also show that contextual variations of available information regarding a given issue positively predict one's knowledge, as does the gap in knowledge between the highly educated vs. the least well educated (for a similar application but in a nonpolitical domain issue, see Hwang and Southwell 2009). What becomes apparent here is that the combination of macrolevel indicators of media systems or information opportunity structures and individual-level characteristics such as media exposure or education levels provides for an opportunity to reconcile microlevel theories on learning from the media (e.g. Eveland 2001) with macrolevel theorizing related to the knowledge gap hypothesis (Tichenor et al. 1970).

European elections have been described as a natural "playground for comparative research" (de Vreese and Boomgaarden 2012, p. 328) and a "laboratory" for comparative social sciences, in particular for electoral research (van der Eijk and Franklin 1996). The fact that the same event takes place at the same time and at regular intervals in, as of 2004, more than 24 different political and media systems, makes a systematic engagement with the interplay of contextual and individuallevel effects possible and necessary. Given that European election studies have been conducted ever since the 1999 election, including a comprehensive battery of media use questions, and given that these surveys have been supplemented in some years by large-scale content analyses of media coverage in national newspapers and television (de Vreese et al. 2006; Schuck et al. 2011) important insights have been generated regarding the effects of media use and their conditionality.

Some contributions in this area examine the interplay between characteristics of the national information environment and individual exposure to certain types of media contents, relying on a linkage approach. Regarding the effect of media on political engagement and voting behavior, Schuck et al. (2016) investigation provides a fairly comprehensive and innovative strategy to model contextual variations in the effect of media exposure on individuals' voting behavior, here turnout. Combining 
a large-scale media content analysis of a sample of national news media across 27 EU Member States with representative panel surveys conducted in each country, they show that the level of conflict framing in media coverage of campaign news significantly varies across countries, and more importantly, the effect of conflict framing exposure on voter turnout significantly depends on EU polity evaluations in a given country (i.e. the tone toward the EU adopted in the national media as a whole). Public satisfaction with democracy was influenced by individual exposure to positive news about the democratic function of the EU, and this effect was found to be stronger in countries in which there was a dominantly positive message flow about the EU, so individual media exposure and the country information environment reinforced each other (Desmet et al. 2015). Once more utilizing a linkage technique, van Spanje and de Vreese (2014) found that citizens across the 27 EU Member States are more likely to support Eurosceptic parties when they are exposed to more negative coverage of the EU. Further, they found that, especially when mainstream parties of a given nation hold highly divergent stances with regard to European integration, the media exposure of the benefit ensuing from the EU significantly lowered the likelihood of voting for Eurosceptic parties.

Studies have also looked beyond the distribution of political knowledge and patterns of voting behavior across different contexts. Based on the seminal work of Jamieson and Cappella (1997), which argues in favor of a relationship between strategy framing in the news and political cynicism among the public, Schuck et al. (2013) have argued that this effect likely depends on the functioning of a country's political system. They argue that citizens' level of cynicism towards a European Parliament election campaign is shaped by both individual-level and contextual-level factors. They found that exposure to strategic, game-framed news (i.e. news articles depicting politics as strategic games among political actors) decreased political cynicism among the more politically engaged. At the same time, they also found that exposure to strategic, game-framed news significantly increased cynicism towards EP elections, especially within political contexts that are characterized by high levels of democratization and higher-quality governance (for a similar finding, see also Desmet et al. 2015). Moreover, while attitudes towards EU membership for Turkey were not driven by individual exposure to EU news coverage, it was shown that the effect of individuals' attitudes towards immigration on support for EU membership for Turkey was stronger in those countries in which the mass mediated information flow about the EU was predominantly negative (Azrout et al. 2012).

Yet another study drawing on European election data, carried out by Wilson and Hobolt (2014), examined citizens' attribution of responsibility between national vs. EU-wide governmental bodies using the 2009 European Election Study (EES) Voter Survey, coupled with the EES media study and their own expert survey. They found that, while political knowledge is positively correlated the with "correct" attribution of responsibility (measured as the discrepancy between citizens' attribution and expert opinions) regarding certain EU issues, a negative media tone and party polarization-which represents the politicization of topics and, therefore, opportunities for learning about such issues-increases the correct allocations of responsibility to the EU over national political actors. In sum, this set of studies, drawing as it does on data collection in the framework of PIREDEU for the 2009 European 
Elections, demonstrates the importance of relying on multiple data sources beyond survey data. In particular, the fact that PIREDEU data included a systematic media content analysis in all EU Member States at that time, and that such content data could either be used to operationalize national information environments or to link up to individual media use measures, was an important impetus for multilevel work on the consequences of media for a range of political outcome variables.

Additional studies examine the consequences of media use on attitudes towards political or media systems in a comparative perspective. Tsfati and Ariely (2014) have found that trust towards media is significantly shaped by general trust, exposure to television news and to newspapers across 44 countries, while a post-materialistic culture, or the aggregate-level political culture stressing higher order needs such as individual freedom and self-expression over physical security or economic endurance, tends to lower people's trust in media. Similarly, Lelkes (2016)—using ESS data across 28 countries - reveals that the degree of press-party parallelism of media significantly conditions the effect of media consumption on trust vis-à-vis political institutions, and of whether an individual has supported the current governing coalition ("winner vs. loser").

Few studies have turned towards the consequences of using new media. Focusing on Sub-Saharan Africa and on Asia, Nisbet, Stoycheff, and Pearce (2012) have examined the impact of Internet use on attitudes toward regime legitimacy ("demand for democracy"). They found that, while individual-level Internet use increases citizens' demand for democracy, this relationship is more pronounced in countries with higher democratization and with higher Internet penetration rates at the contextual level. In a similar vein, Barnidge et al. (2018) found that the effects of individuals' social network heterogeneity in predicting political expression on social media are much higher for countries with less freedom of expression.

Lastly, a novel and promising aspect in the comparative communication literature is the conduct of identical experiments at the same time, in different national contexts. Taking such an approach, Hameleers et al. (2018) investigated the effects of populist communication messages on political engagement, and found that in particular anti-elitism cues in populist messages led to greater engagement in those countries in which the unemployment rate was high. While investment in and coordination of such comparative experimental designs are demanding, including the proper specification of stimulus material, they may be important avenues to move forward in terms of the generalizability of the causal structures demonstrated by experimentation.

\section{Conclusion: Ways and Challenges Ahead}

Communication, in particular explanations and consequences of media use, should be studied in conjunction between microlevel processes and macrolevel influences. While this was already acknowledged by communication scholars decades ago (McLeod and Blumler 1987; Paisley 1984; Pan and McLeod 1991), a systematic and statistical engagement with the interplay between these different levels of influence, based on large- $N$ study designs, is still only a marginal (albeit growing) 
phenomenon in the literature, as described by our review of the state-of-the-art. While the insights that have been generated offer some degree of theoretical convergence, and hence important insights into theorizing of communication processes, much work remains to be done. In what follows, we first discuss the generated empirical insights in a wider context, followed by a critical assessment of the state-ofthe-art. We then conclude by highlighting the challenges faced by the comparative study of media use and media effects, and how the field could move forward.

A general conclusion from the findings sketched above is that context does indeed matter; it either structures individual cognitions, attitudes, and behaviors directly in a predictable way, or it further illuminates the boundary conditions of individual influence processes. In particular, the literature on antecedents and the consequences of media use-especially for political learning — consistently highlights the role played by media system characteristics. Media systems, when characterized by a high degree of journalistic professionalism, lesser press-party parallelism, or low commercialization of media markets (e.g. a stronger public broadcasting system) appear to lead directly to high levels of news consumption, or to knowledge gains in the realm of politics. By contrast, in media systems with higher commercialization or market segmentations, people are less likely to follow news and current affairs programming or learn about political processes. Such system characteristics are conceptualized and theorized as opportunity structures that facilitate (or disinhibit) exposure or learning (Aalberg et al. 2010; Curran et al. 2009; Fraile and Iyengar 2014). In some instances, such opportunities not only raise media use and learning processes directly, but also influence individuals' motivations or interests, which in turn trigger these outcomes. The substantial amount of studies in this particular area therefore converges towards a consistent picture of opportunity structures as an important driver of political learning from media. It might be possible to trace a consolidation of the theoretical underpinning of such theorizing to Hallin and Mancini's (2004) seminal discussion of national media systems.

Empirical evidence is more scattered in other areas, and arguably does not lead to more general theorizing. This particularly applies to studies that look at information environments, i.e., the concrete outputs of national media systems as conditioning the effects of individual media consumption on various types of "attitudes" (rather than learning). In such studies, the theorizing of the boundary conditions appears to tend less towards converging on a more general idea of why different information environments matter. Do they matter because of the fact that dominant characteristics of such information environments are competing against alternative sources of information such as interpersonal communication (Boomgaarden 2014; SchmittBeck 2003; Southwell and Yzer 2007), and hence interfere with the information that individuals encounter directly? Or do they matter because they make information that individuals receive directly more or less important, so that it can stand out among the dominant information flows? It seems that theorizing in such studies is more ad hoc, driven by the particular research interests or data availability. Based on the evidence, inferring a general picture of how and why information environments matter for media effects in more general terms-especially for its attitudinal consequences-seems a daunting task so far, and the field would do well to invest 
more heavily in the conceptual and theoretical underpinnings that would apply more generally.

An important point to add here relates to the observation that the literature reviewed above, including much of the early calls for more comparative communication research that specifically deals with media use and its effects, mostly emanated from the subfield of political communication. While acknowledging that we might have neglected important prior works from other subfields of communication in the review process, it appears that political communication scholars have particularly embraced the use of multilevel models as a methodological toolkit for systematic comparative research of media use and media effects (see Schmidt-Catran et al. 2019 in this special issue). Our assumption is that this is largely due to the types of data that are available to this particular subdiscipline (often facilitated by cross-national collaborations of comparative election studies) and the theoretical impetus put forward by a number of seminal scholars in the field, most of whose intellectual origins can be traced back to the field of comparative politics (also see Schmitt-Beck 2019 in this special issue). Surely there has been an attempt to embrace systematic comparative inquiries in other subfields of communication science as well (see Esser and Hanitzsch 2012). It is arguably in its earlier stage-at least for large-N, multilevel comparative approaches. Our hope would be to see other areas of communication science following suit, areas in which contextual factors may be equally important, e.g. health communication, organizational communication, or media economics.

As in many other areas of comparative research, data availability appears to constitute a central hurdle to the further development of comparative studies of communication processes, and this issue has both genuine practical and conceptual/ theoretical implications. Starting with the latter, the logic of case selection remains pretty much driven by (post hoc) data availability, and not by theoretical concerns that reveal important insights regarding the regularities and its contingencies of communication processes. This is for instance evident even when it comes to looking at media systems. On a global scale, media systems would offer much greater variation than is utilized in typical empirical studies in the field, which primarily-except for a few cases-look at European countries cross-sectionally. If the aim is to understand the boundary conditions imposed by different media systems on media use patterns or learning effects, it would be theoretically desirable to include a much wider range of media systems across a much broader geographical context, and also over time. This would allow researchers to examine the impact of (more meaningful) variations in the characteristics of interest at national levels. But such data is usually gathered externally (such as in the case of the European Social Survey or the European Value Survey), or driven by certain geographically confined events (such as in the case of European elections), which limits the types of macro-micro dynamics assessments to these limited cases only. Also, media systems data (not to speak of information environment data) are often more readily available for certain regions of the world than for others, which again imposes practical constraints.

But even if comparative data are available, the type of measurement does not always speak to the questions that communication scholars may be interested in addressing. Media use batteries in large-scale (comparative) surveys are oftentimes 
much more limited than one hopes that they might be (Prior 2009b; Slater 2004), and often do not fully capture the types of usage that would be needed in order to investigate explanations or effects of type, content, or genre-specific consumption (Prior 2013). This imperfect measurement of media exposure is in particular true for media effects studies which wish to link exposure to specific media outlets and content data (i.e. linkage analysis: De Vreese et al. 2017), where it is often argued that it produces a severe downward bias in estimated media effects (Scharkow and Bachl 2017). Assessing outlet-specific or content-specific exposure requires tediously long and detailed measurements, and existing data collection efforts often do not allocate the appropriate space to do so. The few examples that have done such in relation to European elections have, however, generated important insights. Another aspect that comes into play here is the availability of media content data to either operationalize information environments, or to link up with individual media use. Conducting large-scale content analyses across multiple countries and languages, which would allow for multilevel modeling, have long been a laborintensive and costly task, and except for the PIREDEU project, such an endeavor is very rare at best. However, the recent developments in automated content analysis and text-as-data approaches (Proksch et al. 2018; Lind et al. n.d.) are starting to provide more accessible alternatives in this regard.

A further aspect that also requires greater attention than it has hitherto received is the matter of conceptual equivalence, measurement equivalence, and (study) administration equivalence. Conceptual equivalence (Hui and Triandis 1985) denotes a representation of common, established and shared knowledge between the (proposed) theory and empirical phenomenon in question. While this constitutes a very basic condition necessary for making cross-cultural or cross-national comparisons, the comparability and equivalence of concepts and their interpretations have always been a problematic endeavor (see Wirth and Kolb 2004). This issue is sometimes discussed within the context of meaning (semantic) equivalence (i.e. whether the concept in question is interpreted similarly across different national contexts), within the context of measurement equivalence (regarding the operationalization and measurement of the concepts across contexts: also see Cieciuch et al. 2019 in this special issue), or in terms of the equivalence of study administration (regarding the standardization of research designs, instruments, and instructions). While all of these considerations aim to maximize the theoretical and empirical comparability of the findings at every stage of research, it is ironic that such multiple considerations often work in opposite directions. For instance, it is now a very common practice (at least for large-scale comparative studies) to impose identical wordings and study administrative procedures, yet imposing such restrictions does not necessarily yield or aid meaning and conceptual equivalence across all contexts. Many of the large$\mathrm{N}$, multilevel comparative studies that have been published to date are rather silent about this issue in evaluating their findings due to the (largely) secondary-analysis nature of the study. While this issue is arguably highly context- and research question-specific, it is our observation that a more thorough and systematic evaluation of this matter is needed.

In order to move the field forward, two additional aspects stand out. First, standardization of data collection and data sharing, both in terms of survey data, but 
even more so relating to detailed media content data must be addressed. If individual projects, for instance national election studies, were to adhere to standardized, highly calibrated approaches to measure media use in their surveys and abide by these approaches in consecutive waves, combining national surveys into comparative data sets would offer a far greater potential beyond long-standing cross-national survey projects. Also, the latter should invest more in listening to the needs of communication scholars. Second, international cooperation now seems more and more imperative, with funding opportunities not only for networking (such as in COST action), but also for data collection. While there is still much to gain from large$\mathrm{N}$, multilevel comparative communication research, as has become evident from the review provided here, the road ahead is, at best, bumpy. Placing stronger emphasis on both the theoretical need to invest in comparative studies in order to establish the boundary of existing theorizing, in combination with establishing stronger infrastructures to enable this type of work to be done, would be needed in order to advance the field of comparative communication.

Funding Open access funding provided by University of Vienna.

Open Access This article is distributed under the terms of the Creative Commons Attribution 4.0 International License (http://creativecommons.org/licenses/by/4.0/), which permits unrestricted use, distribution, and reproduction in any medium, provided you give appropriate credit to the original author(s) and the source, provide a link to the Creative Commons license, and indicate if changes were made.

\section{References}

Aalberg, Toril, Peter van Aelst and James Curran. 2010. Media systems and the political information environment: A cross-national comparison. The International Journal of Press/Politics 15:255-271.

Aalberg, Toril, Arild Blekesaune and Eiri Elvestad. 2013. Media choice and informed democracy: Toward increasing news consumption gaps in Europe? The International Journal of Press/Politics 18:281-303.

Althaus, Scott L., and David Tewksbury. 2000. Patterns of Internet and traditional news media use in a networked community. Political Communication 17:21-45.

Althaus, Scott L., Anne M. Cizmar and James G. Gimpel. 2009. Media supply, audience demand, and the geography of news consumption in the United States. Political Communication 26:249-277.

Anduiza, Eva, Eva Anduiza Perea, Michael James Jensen and Laia Jorba. 2012. Digital media and political engagement worldwide: A comparative study. Cambridge University Press.

Azrout, Rachid, Joost van Spanje and Claes de Vreese. 2012. When news matters: Media effects on public support for European Union enlargement in 21 countries. JCMS: Journal of Common Market Studies 50:691-708.

Barnidge, Matthew, Brigitte Huber, Homero Gil de Zúñiga and James H. Liu. 2018. Social media as a sphere for "risky" political expression: A twenty-country multilevel comparative analysis. The International Journal of Press/Politics 23:161-182.

Bartsch, Anne, Roland Mangold, Reinhold Viehoff and Peter Vorderer. 2006. Emotional gratifications during media use - An integrative approach. Communications 31:261-278.

Beck, Paul Allen, Russell J. Dalton, Steven Greene, and Robert Huckfeldt. 2002. The social calculus of voting: Interpersonal, media, and organizational influences on presidential choices. American Political Science Review 96: 57-73.

Becker, Mark W., Reem Alzahabi and Christopher J. Hopwood. 2-13. Media multitasking is associated with symptoms of depression and social anxiety. Cyberpsychology, Behavior, and Social Networking 16:132-135.

Blekesaune, Arild, Eiri Elvestad and Toril Aalberg. 2012. Tuning out the world of news and current affairs-An empirical study of Europe's disconnected citizens. European Sociological Review 28:110-126.

Blumler, Jay. 1979. The role of theory in uses and gratifications studies. Communication Research, 6: 9-36. 
Blumler, Jay G., and Michael Gurevitch. 1975. Towards a comparative framework for political communication research. In Political communication: Issues and strategies for research, edited by Steven $\mathrm{H}$. Chaffee, 165-193. Beverly Hills, CA: Sage.

Blumler, Jay G., and Michael Gurevitch. 1995. The crisis of public communication. London, UK: Routledge.

Blumler, Jay G., Jack M. McLeod and Karl Erik Rosengren. 1992. Comparatively speaking: Communication and culture across space and time. Newbury Park, CA: Sage

Boomgaarden, Hajo G. 2014. Interpersonal and mass mediated political communication. In Political communication, ed. Carsten Reinemann, 469-488. Berlin: Walter de Gruyer.

Bright, Jonathan. 2018. Explaining the emergence of political fragmentation on social media: The role of ideology and extremism. Journal of Computer-Mediated Communication 23:17-33.

Brüggemann, Michael, Sven Engesser, Florin Büchel, Edda Humprecht and Laia Castro. 2014. Hallin and Mancini revisited: Four empirical types of western media systems. Journal of Communication 64:1037-1065.

Bryant, Jennings, and Mary Beth Oliver. Eds. 2009. Media effects: Advances in theory and research. New York: Routledge.

Campbell, Scott W., and Nojin Kwak. 2010. Mobile communication and social capital: An analysis of geographically differentiated usage patterns. New Media \& Society 12:435-451.

Carpini, Michael X. Delli, and Scott Keeter. 1996. What Americans know about politics and why it matters. New Haven, CT: Yale University Press.

Castells, Manuel. 2011. The rise of the network society (2nd ed.). Chichester, UK: John Wiley \& Sons.

Castro, Laia, Lilach Nir and Morten Skovsgaard. 2018. Bridging gaps in cross-cutting media exposure: The role of public service broadcasting. Political Communication, online first.

Cho, Jaeho. 2011. The geography of political communication: Effects of regional variations in campaign advertising on citizen communication. Human Communication Research 37:434-462.

Cieciuch, Jan, Eldad Davidov, Peter Schmidt and René Algesheimer. 2019. How to obtain comparable measures for cross-national comparisons. In Cross-national comparative research - analytical strategies, results and explanations. Sonderheft Kölner Zeitschrift für Soziologie und Sozialpsychologie. Eds. Hans-Jürgen Andreß, Detlef Fetchenhauer and Heiner Meulemann. Wiesbaden: Springer VS. https://doi.org/10.1007/s11577-019-00598-7.

Clark, Nicholas. 2014. The EU's information deficit: Comparing political knowledge across levels of governance. Perspectives on European Politics and Society 15:445-463.

Curran, James. 2011. Media and democracy. New York: Routledge.

Curran, James, Shanto Iyengar, Anker Brink Lund and Inka Salovaara-Moring. 2009. Media system, public knowledge and democracy: A comparative study. European Journal of Communication 24:5-26.

De Vreese, Claes H., Susan A. Banducci, Holli A. Semetko and Hajo G. Boomgaarden. 2006. The news coverage of the 2004 European Parliamentary election campaign in 25 countries. European Union Politics 7:477-504.

De Vreese, Claes, and Hajo G. Boomgaarden. 2012. Comparing news on Europe: Elections and beyond. In The Handbook of Comparative Communication Research, ed. Frank Esser and Thomas Hanitzsch, 327-340. London, UK: Routledge.

De Vreese, Claes H., and Peter Neijens. 2016. Measuring media exposure in a changing communications environment. Communication Methods and Measures, 10: 69-80.

De Vreese, Claes H., Mark Boukes, Andreas Schuck, Rens Vliegenthart, Linda Bos and Yph Lelkes. 2017. Linking survey and media content data: Opportunities, considerations, and pitfalls. Communication Methods and Measures 11:221-244.

Delli Carpini, Michael X., and Scott Keeter. 1993. Measuring political knowledge: Putting first things first. American Journal of Political Science 37:1179-1206.

Desmet, Pieterjan, Joost van Spanje and Claes de Vreese. 2015. Discussing the democratic deficit: Effects of media and interpersonal communication on satisfaction with democracy in the European Union. International Journal of Communication 9:3177-3198.

Dilliplane, Susanna, Seth K. Goldman and Diana C. Mutz. 2013. Televised exposure to politics: New measures for a fragmented media environment. American Journal of Political Science 57:236-248.

Donohew, Lewis, Philip Palmgreen, and Jay D. Rayburn. 1987. Social and psychological origins of media use: A lifestyle analysis. Journal of Broadcasting \& Electronic Media 31:255-278.

Edelstein, Alex S. 1982. Comparative communication research. Beverly Hills, CA: Sage.

Elenbaas, Matthijs, Claes de Vreese, Andreas Schuck and Hajo Boomgaarden. 2014. Reconciling passive and motivated learning: The saturation-conditional impact of media coverage and motivation on political information. Communication Research 41:481-504. 
Elvestad, Eiri, and Arild Blekesaune. 2008. Newspaper readers in Europe: A multilevel study of individual and national differences. European Journal of Communication 23:425-447.

Esser, Frank, and Thomas Hanitzsch. 2012. On the why and how of comparative inquiry in communication studies. In The handbook of comparative communication research, ed. Frank Esser and Thomas Hanitzsch, 3-22. London, UK: Routledge.

Esser, Frank, and Barbara Pfetsch. 2004. Meeting the challenges of global communication and political integration: The significance of comparative research in a changing world. In Comparing political communication: Theories, cases, and challenges, ed. Frank Esser and Barbara Pfetsch, 384-410. New York: Cambridge University Press.

Esser, Frank, Claes H. de Vreese, Jesper Strömbäck, Peter Van Aelst, Toril Aalberg, James Stanyer, Günther Lengauer, Rosa Berganza, Guido Legnante, et al. 2012. Political information opportunities in Europe: A longitudinal and comparative study of thirteen television systems. The International Journal of Press/Politics 17:247-274.

Eveland, William P., Jr. 2001. The cognitive mediation model of learning from the news: Evidence from nonelection, off-year election, and presidential election contexts. Communication Research 28:571-601.

Fletcher, Richard, and Rasmus Kleis Nielsen. 2017. Are news audiences increasingly fragmented? A crossnational comparative analysis of cross-platform news audience fragmentation and duplication. Journal of Communication 67:476-498.

Fraile, Marta, and Shanto Iyengar. 2014. Not all news sources are equally informative: A cross-national analysis of political knowledge in Europe. The International Journal of Press/Politics 19:275-294.

Goldman, Seth K., and Diana C. Mutz. 2011. The friendly media phenomenon: A cross-national analysis of cross-cutting exposure. Political Communication 28:42-66.

Hallin, Daniel. C., and Paolo Mancini. 2004. Comparing media systems: Three models of media and politics. Cambridge, UK: Cambridge University Press

Hallin, Daniel. C., and Paolo Mancini. 2012. Comparing media systems beyond the Western world. New York, NY: Cambridge University Press.

Hameleers, Michael, Linda Bos, Nayla Fawzi, Carsten Reinemann, Ioannis Andreadis, Nicoleta Corbu, Christian Schemer et al. 2018. Start spreading the news: A comparative experiment on the effects of populist communication on political engagement in sixteen European countries. The International Journal of Press/Politics 23:517-538.

Hanitzsch, Thomas, and Frank Esser. 2012. Challenges and perspectives of comparative communication inquiry. In The handbook of comparative communication research, ed. Frank Esser and Thomas Hanitzsch, 501-516. London, UK: Routledge.

Hanitzsch, Thomas, Folker Hanusch, Claudia Mellado, Maria Anikina, Rosa Berganza, Incilay Cangoz, Mihai Coman, Basyouni Hamada, María Elena Hernández, Christopher D. Karadjov, Sonia Virginia Moreira, Peter G. Mwesige, Patrick Lee Plaisance, Zvi Reich, Josef Seethaler, Elizabeth A. Skewes, Dani Vardiansyah Noor and Edgar Kee Wang Yuen. 2011. Mapping journalism cultures across nations. Journalism Studies 12:273-293.

Hui, C. Harry, and Harry C. Triandis. 1985. Measurement in cross-cultural psychology: A review and comparison of strategies. Journal of Cross-Cultural Psychology 16:131-152.

Hwang, Yoori, and Brian G. Southwell. 2009. Science TV news exposure predicts science beliefs: Real world effects among a national sample. Communication Research 36:724-742.

Iyengar, Shanto, James Curran, Anker Brink Lund, Inka Salovaara-Moring, Kyu S. Hahn and Sharon Coen. 2010. Cross-national versus individual-level differences in political information: A media systems perspective. Journal of Elections, Public Opinion and Parties 20:291-309.

Jamieson, Kathleen Hall, and Joseph N. Cappella. 1997. Setting the record straight: Do ad watches help or hurt? Harvard International Journal of Press/Politics 2:13-22.

Jerit, Jennifer. 2009. Understanding the knowledge gap: The role of experts and journalists. The Journal of Politics 71:442-456.

Jerit, Jennifer, Jason Barabas and Toby Bolsen. 2006. Citizens, knowledge, and the information environment. American Journal of Political Science 50:266-282.

Kalogeropoulos, Antonis. 2018. Online news video consumption: A comparison of six countries. Digital Journalism 6:651-665.

Kalogeropoulos, Antonis, Samuel Negredo, Ike Picone and Rasmus Kleis Nielsen. 2017. Who shares and comments on news? A cross-national comparative analysis of online and social media participation. Social Media+ Society 3:1-12.

Katz, Elihu, Jay G. Blumler and Michael Gurevitch. 1973. Uses and gratifications research. The Public Opinion Quarterly 37:509-523. 
Kim, Junghyun, Robert LaRose and Wei Peng. 2009. Loneliness as the cause and the effect of problematic Internet use: The relationship between Internet use and psychological well-being. CyberPsychology \& Behavior 12:451-455.

Knobloch, Silvia. 2003. Mood adjustment via mass communication. Journal of Communication 53:233-250.

Knobloch-Westerwick, Silvia, and Steven B. Kleinman. 2012. Preelection selective exposure: Confirmation bias versus informational utility. Communication Research 39:170-193.

Lauf, Edmund. 2001. Research note: The vanishing young reader: Sociodemographic determinants of newspaper use as a source of political information in Europe, 1980-98. European Journal of Communication 16:233-243.

Lelkes, Yphtach. 2016. Winners, losers, and the press: the relationship between political parallelism and the legitimacy gap. Political Communication 33:523-543.

Lind, Fabienne, Jakob-Moritz Eberl, Tobias Heidenreich and Hajo Boomgaarden. 2018. Multilingual dictionary construction: Comparing different approaches for the measurement of migration frames. Paper presented at the 68th Annual Conference of the International Communication Association, Prague, Czech Republic.

Livingstone, Sonia. 1998. Mediated childhoods: A comparative approach to young people's changing media environment in Europe. European Journal of communication 13:435-456

Livingstone, Sonia. 2003. On the challenges of cross-national comparative media research. European Journal of Communication 18:477-500.

Lizardo, Omar, and Sara Skiles. 2009. Highbrow omnivorousness on the small screen? Cultural industry systems and patterns of cultural choice in Europe. Poetics 37:1-23.

Loveless, Matthew. 2015. Contextualizing media behavior: Media environments and individuals' media use in the European Union. Central European Journal of Communication 8:112-131.

McLeod, Jack, and Jay Blumler. 1987. The macrosocial level of communication science. In Handbook of communication science, ed. Charles R. Berger and Steven H. Chaffee, 271-322. Newbury Park, CA: Sage

McLeod, Jack M., and Nam-Ji Lee. 2012. Comparative research designs: Toward a multilevel approach. In The handbook of comparative communication research, ed. Frank Esser and Thomas Hanitzsch, 430-444. London, UK: Routledge.

McLeod, Jack M., Gerald M. Kosicki and Douglas M. McLeod. 2010. Levels of analysis and communication Science. In The handbook of communication science (2nd ed), ed. Michael E. Roloff, David R. Roskos-Ewoldsen and Charles R. Berger, 183-200. Thousand Oaks, CA: Sage Publications.

McLeod, Jack M., Dietram A. Scheufele and Patricia Moy. 1999. Community, communication, and participation: The role of mass media and interpersonal discussion in local political participation. Political Communication 16:315-336.

McLuhan, Marshall, and Bruce R. Powers. 1989. The global village: Transformations in world life and media in the 21st century. Oxford, UK: Oxford University Press

Nabi, Robin L., and Mary Beth Oliver. 2009. The SAGE handbook of media processes and effects. Thousand Oaks, CA: Sage.

Neuman, W Russell. 2016. The digital difference: Media technology and the theory of communication effects. London, UK: Harvard University Press.

Nielsen, Rasmus Kleis, and Kim Christian Schrøder. 2014. The relative importance of social media for accessing, finding, and engaging with news: An eight-country cross-media comparison. Digital Journalism 2:472-489.

Nir, Lilach. 2012. Public space: How shared news landscapes close gaps in political engagement. Journal of Broadcasting \& Electronic Media 56:578-596.

Nisbet, Erik C., Elizabeth Stoycheff and Katy E. Pearce. 2012. Internet use and democratic demands: A multinational, multilevel model of Internet use and citizen attitudes about democracy. Journal of Communication 62:249-265.

Paisley, William. 1984. Communication in the communication sciences. In Progress in the communication sciences, ed. Brenda Dervin and Melvin Voigt, 1-43. Norwood, NJ: Ablex.

Pan, Zhongdang, and Jack M. McLeod. 1991. Multilevel analysis in mass communication research. Communication Research 18:140-173.

Papacharissi, Zizi, and Alan M. Rubin. 2000. Predictors of Internet use. Journal of Broadcasting \& Electronic Media 44:175-196.

Papathanassopoulos, Stylianos, Sharon Coen, James Curran, Toril Aalberg, David Rowe, Paul Jones, Hernando Rojas and Rod Tiffen. 2013. Online threat, but television is still dominant: A comparative study of 11 nations' news consumption. Journalism Practice 7:690-704. 
Pfetsch, Barbara, and Frank Esser. 2014. Political communication in comparative perspective: Key concepts and new insights (Vol. 18), 97-105. Berlin: De Gruyter Mouton.

Popescu, Marina, Gabor Toka, Tania Gosselin and Jose Santana Pereira. 2011. European media systems survey 2010: Results and documentation. Research report. Colchester, UK: Department of Government, University of Essex. http://www.mediasystemsineurope.org (Date of access: 20 Nov. 2018).

Potter, W. James. 2011. Conceptualizing mass media effect. Journal of Communication 61:896-915.

Price, Vincent, and John Zaller. 1993. Who gets the news? Alternative measures of news reception and their implications for research. Public Opinion Quarterly 57:133-164.

Prior, Markus. 2007. Post-broadcast democracy: How media choice increases inequality in political involvement and polarizes elections. New York: Cambridge University Press.

Prior, Markus. 2009a. Improving media effects research through better measurement of news exposure. The Journal of Politics 71:893-908.

Prior, Markus. 2009b. The immensely inflated news audience: Assessing bias in self-reported news exposure. Public Opinion Quarterly 73:130-143.

Prior, Markus. 2013. The challenge of measuring media exposure: Reply to Dilliplane, Goldman, and Mutz. Political Communication 30:620-634.

Proksch, Sven-Oliver, Will Lowe, Jens Wäckerle and Stuart Soroka. 2018. Multilingual sentiment analysis: A new approach to measuring conflict in parliamentary speeches. Legislative Studies Quarterly. https://doi.org/10.1111/lsq.12218

Putman, Robert D. 2000. Bowling alone: The collapse and revival of American community. New York: Simon \& Schuster.

Roe, Keith. 2000. Adolescents' media use: a European view. Journal of Adolescent Health 27:15-21.

Ruggiero, Thomas E. 2000. Uses and gratifications theory in the 21 st century. Mass Communication \& Society 3:3-37.

Scharkow, Michael, and Marko Bachl. 2017. How measurement error in content analysis and self-reported media use lead to minimal media effect findings in linkage analyses: A simulation study. Political Communication 34:323-343.

Schmidt-Catran, Alexander W., Malcolm Fairbrother and Hans-Jürgen Andreß. 2019. Multilevel models for the analysis of comparative survey data: Common problems and some solutions. In Cross-national comparative research - analytical strategies, results and explanations. Sonderheft Kölner Zeitschrift für Soziologie und Sozialpsychologie. Eds. Hans-Jürgen Andreß, Detlef Fetchenhauer and Heiner Meulemann. Wiesbaden: Springer VS. https://doi.org/10.1007/s11577-019-006907-9.

Schmitt-Beck, Rüdiger. 2003. Mass communication, personal communication and vote choice: The filter hypothesis of media influence in comparative perspective. British Journal of Political Science 33:233-259.

Schmitt-Beck, Rüdiger. 2019. Political systems and electoral behavior: A review of internationally comparative multilevel research. In Cross-national comparative research - analytical strategies, results and explanations. Sonderheft Kölner Zeitschrift für Soziologie und Sozialpsychologie. Eds. Hans-Jürgen Andreß, Detlef Fetchenhauer and Heiner Meulemann. Wiesbaden: Springer VS. https://doi.org/ 10.1007/s11577-019-00608-8.

Schoonvelde, Martijn. 2014. Media freedom and the institutional underpinnings of political knowledge. Political Science Research \& Methods 2:163-178.

Schuck, Andreas R., Hajo G. Boomgaarden and Claes H. de Vreese. 2013. Cynics all around? The impact of election news on political cynicism in comparative perspective. Journal of Communication 63:287-311.

Schuck, Andreas R., Rens Vliegenthart and Claes H. de Vreese. 2016. Who's afraid of conflict? The mobilizing effect of conflict framing in campaign news. British Journal of Political Science 46:177-194.

Schuck, Andreas R., Georgios Xezonakis, Matthijs Elenbaas, Susan A. Banducci and Claes H. de Vreese. 2011. Party contestation and Europe on the news agenda: The 2009 European Parliamentary Elections. Electoral Studies 30:41-52.

Sears, David O., and Jonathan L. Freedman. 1967. Selective exposure to information: A critical review. Public Opinion Quarterly 31:194-213.

Sehl, Annika, Alessio Cornia, Lucas Graves, and Rasmus Kleis Nielsen. 2018. Newsroom integration as an organizational challenge: Approaches of European public service media from a comparative perspective. Journalism Studies, online advanced publication. https://doi.org/10.1080/1461670X.2018. 1507684

Seymour-Ure, Colin. 1974. The political impact of mass media. Beverly Hills, CA: Sage. 
Shah, Dhaven V., Nojin Kwak and R. Lance Holbert. 2001. "Connecting" and "disconnecting" with civic life: Patterns of Internet use and the production of social capital. Political Communication 18:141-162.

Shehata, Adam, and Jesper Strömbäck. 2011. A matter of context: A comparative study of media environments and news consumption gaps in Europe. Political Communication 28:110-134.

Siebert, Fred, Theodore Bernard Peterson, Theodore Peterson and Wilbur Schramm. 1956. Four theories of the press: The authoritarian, libertarian, social responsibility, and Soviet communist concepts of what the press should be and do. Chicago, IL: University of Illinois press.

Slater, Michael D. 2004. Operationalizing and analyzing exposure: The foundation of media effects research. Journalism \& Mass Communication Quarterly 81:168-183.

Slater, Michael D. 2007. Reinforcing spirals: The mutual influence of media selectivity and media effects and their impact on individual behavior and social identity. Communication Theory 17:281-303.

Slater, Michael D. 2015. Reinforcing spirals model: Conceptualizing the relationship between media content exposure and the development and maintenance of attitudes. Media Psychology 18:370-395.

Slater, Michael D., Leslie Snyder and Andrew F. Hayes. 2006. Thinking and modeling at multiple levels: The potential contribution of multilevel modeling to communication theory and research. Human Communication Research 32:375-384.

Southwell, Brian G., and Marco C. Yzer. 2007. The roles of interpersonal communication in mass media campaigns. Communication Yearbook 31:419-462.

Teune, Henry, and Adam Przeworski. 1970. The logic of comparative social inquiry. New York: Wiley.

Tichenor, Phillip J., George A. Donohue and Clarice N. Olien. 1970. Mass media flow and differential growth in knowledge. Public Opinion Quarterly 34:159-170.

Tsfati, Yariv, and Gal Ariely. 2014. Individual and contextual correlates of trust in media across 44 countries. Communication Research 41:760-782.

Valkenburg, Patti M, and Jochen Peter. 2013. The differential susceptibility to media effects model. Journal of Communication 63:221-243.

Van der Eijk, Cees, and Mark N. Franklin. 1996. Choosing Europe? The European electorate and national politics in the face of union. Ann Arbor, MI: University of Michigan Press.

Van Spanje, Joost, and Claes de Vreese. 2014. Europhile media and Eurosceptic voting: Effects of news media coverage on Eurosceptic voting in the 2009 European parliamentary elections. Political Communication 31:325-354.

Vliegenthart, Rens. 2012. Analyzing comparative data: Opportunities and challenges. In The handbook of comparative communication research, ed. Frank Esser and Thomas Hanitzsch, 486-500. London, UK: Routledge.

Vorderer, Peter, Christoph Klimmt and Ute Ritterfeld. 2004. Enjoyment: At the heart of media entertainment. Communication Theory 14:388-408.

Wang, Zheng, John M. Tchernev and Tyler Solloway. 2012. A dynamic longitudinal examination of social media use, needs, and gratifications among college students. Computers in Human Behavior 28:1829-1839.

Wilson, Traci L., and Sara B. Hobolt. 2014. Allocating responsibility in multilevel government systems: Voter and expert attributions in the European Union. The Journal of Politics 77:102-113.

Wirth, Werner, and Steffen Kolb. 2004. Designs and methods of comparative political communication research. In Comparing political communication: Theories, cases, and challenges, ed. Frank Esser and Barbara Pfetsch, 87-111. New York: Cambridge.

Zillmann, Dolf. 1988. Mood management through communication choices. American Behavioral Scientist 31:327-341.

Hajo G. Boomgaarden 1977, Ph.D, Prof., Dean of the Faculty of Social Sciences and Professor of Methods in the Social Sciences with a focus on Text Analysis at the Department of Communication, University of Vienna. Areas of research: the coverage and effects of political information on citizens' cognitions, attitudes and behaviors in various domains of media and politics, and developments in automated content analysis techniques. Publications: One bias fits all? Three types of media bias and their effects on party preferences. Communication Research 44, 2015 (with J-M. Eberl and M. Wagner).

Hyunjin Song 1983, Ph.D, University Assistant, Department of Communication, University of Vienna. Areas of research: the influence of interpersonal discussion on political engagement, advanced computational methods such as statistical modeling of social networks. Publications: The dynamics of message selection in online political discussion forums: Self-segregation or diverse exposure? Communication Research 2018 (with J. Cho and G. A. Benefield). 